\title{
ОЦЕНОЧНЫЕ КОННОТАЦИИ ГЕНДЕРНЫХ ПАРЕМИЙ АВАРСКОГО ЯЗЫКА
}

\section{EVALUATIVE CONNOTATIONS OF AVAR PROVERBS}

\section{S. Alieva \\ S. Gamzatova}

Summary: The article is devoted to the study of evaluative semantics of gender proverbs of the Avar language. Pejorative and meliorative gender proverbs are considered, the predominance of proverbs with negative coloring is revealed. The analysis also showed that connotative meaning in proverbs is often expressed implicitly. Often Avar proverbs and saying are formed according to a metaphorical model: An animal Person. The assessment in the gender proverbs of the Avar language has a national and cultural specificity.

Keywords: Avar language, gender, connotation, proverbs, evaluability, stereotype.

$\mathrm{B}$ конце XX - начале XXI века в языкознании возрос интерес к гендерным исследованиям. В центре внимания ученых находятся различные факторы, которые помогают определить, как общество относится к мужчинам и женщинам, каковы стереотипы мужского и женского поведения.

Лингвисты, рассматривая проблему взаимодействия говорящего субъекта и адресата в ситуации общения, используют категорию оценки. Однако многие проблемы, связанные с оценочностью, еще требуют дальнейшего изучения. К ним относится исследование языковых способов выражения оценки. Оценка характеризуется особой структурой, содержащей ряд обязательных факультативных элементов [1, С. 94]. Среди единиц языка, обладающих наиболее яркими возможностями в выражении эмоционально-оценочного отношения к окружающему миру, следует выделить паремии.

Цель данной статьи - проанализировать гендерные паремии аварского языка с точки зрения их аксиологического статуса и национально-культурной специфики.

Источником фактического материала послужили аварские пословицы и поговорки, представленные в Словаре пословиц и поговорок: Авар кицаби ва абиял «Аварские пословицы и поговорки» [2]и в сборнике «Мудрые слова. Пословицы и поговорки народов Кавказа» [3]. Аварские примеры даются с авторским русским переводом.
Алиева Самая Азеровна

к.филол.н., дочент, Дагестанский государственный университет, г. Махачкала

samaya.alieva.00@mail.ru

Гамзатова Сакинат Рустамовна Дагестанский государственный университет,

2. Махачкала

s_gamzatova@bk.ru

Аннотация: Статья посвящена исследованию оценочной семантики гендерных паремий аварского языка. Рассмотрены пейоративные и мелиоративные гендерные паремии, выявлено явное преобладание пословиц с отрицательной окраской. Анализ также показал, что коннотативное значение в паремиях часто выражается имплицитно. Нередко аварские пословицы и поговорки образуются по метафорической модели: Животное $\rightarrow$ Человек. Оценка в гендерных паремиях аварского языка имеет национально-культурную специфику.

Ключевые слова: аварский язык, гендер, коннотация, паремии, оценочность, стереотип.

Характерной особенностью пословиц и поговорок любого народа является их исконно национальное происхождение. Дагестанские пословицы, поговорки, загадки, как и все фольклорное наследие народов Дагестана, стали объектом изучения со второй половины XIX века, когда завершилась долголетняя кровопролитная Кавказская война. В этот период как русские, так и зарубежные ученые занялись систематическим изучением не только жизни кавказских народов и племен, но и их языков и фольклора, а паремии - ценнейший источник национально-культурной информации об истории того или иного этноса.

Дагестанские ученые видят в паремиях «драгоценное словесное богатство». Исследователь аварского языка М.М. Магомедханов, объясняя различие между фразеологизмами и паремиями, отмечал соответствие пословиц и поговорок предложению, при этом они [пословицы] «выражают целое, логически законченное суждение» [4, с. 102], например: Лъимал гьоркьоб гьечlеб ригьин биххи - оч-гІакаялъул даран биххи. Лъимал гьоркьор ругеб ригьин биххи - бащдаб къиямасеб къо. «Расторгнуть бездетный брак, то же самое, что расторгнуть обычную рыночную сделку. Расторгнуть брак с детьми, сродни концу света». [2]. Оба выражения содержат сравнение. Большое значение в аварской семье придается семейным ценностям, а дети - немаловажное условие для возникновения таких ценностей. Об этом свидетельствует и другая аварская пословица: Кто не родил детей, moт не знает любви, у кого они не умирали, тот не знает горя 
[3]. Что женитьба - очень серьезный шаг, говорят паремии: Ч1ужухвей чо балагь; ч1ужуйилан чоги балагь $m 1$ аде ккей - к1иго балагь. «Смерть жены - одно горе, жениться - два горя». О женитьбе сына посоветуйся с десятью, а о разводе-с сотней.

Главная цель пословицы - выразить то, что народ замечал в окружающем его мире, но только в очень краткой форме. Этим и объясняется схожая структура паремий. При создании пословиц и поговорок человек часто использует одинаковые лексические и стилистические средства.

Следует отметить неоднозначность пословицы, поэтому паремии можно изучать как с позиции лингвистики, так и фольклора. Для лингвистики пословица - языковой знак. Являясь устойчивым языковым образованием, пословица наделена переносным значением, которое используется в дидактических целях [5, с. 22].

Оценочная характеристика (коннотация) гендерных паремий имеет немаловажное значение. Ю.Д. Апресян рассматривает коннотацию как «семантическую ассоциацию», «несущественные, но устойчивые признаки выражаемого ею понятия, которые воплощают принятую в данном языковом коллективе оценку соответствующего предмета или факта действительности» [6, с. 159]. Они не входят непосредственно в лексическое значение слова и не являются следствиями или выводами из него.

Коннотативное значение чаще всего не лежит на поверхности, оно выражено имплицитно, поэтому приводимые в толковых и двуязычных словарях описания зачастую не содержат подобные значения. Для подтверждения можно обратиться к конкретному примеру на аварском языке. Так, при объяснении лексемы х1ама «осел» в словаре будет отмечено, что это «самец ослицы». При этом не будет указания на переносный смысл: человек очень много работающий. В русском языке слово «осел» применительно к человеку обозначает такие качества, как упрямство и глупость.

В гендерных паремиях часто встречаются наименования родственников. При этом следует отметить, что в парах «тесть - теща», «отчим - мачеха» имена мужского пола лишены, или почти лишены коннотаций, а имена родственников женского пола, напротив, насыщены ими. Например, слово «свекровь» ассоциируется в сознании носителей языка с несправедливостью, зловредностью, мелочностью и болтливостью, подобное обусловлено существующими в обществе стереотипами, что наглядно демонстрирует следующая аварская пословица Жийго нуслъун йикlаго, якьад рихарай, жийго якьадлъун йикlаго нус рихарай (букв. «Будучи снохой, свекровь ненавидевшая, став свекровью, сноху ненавидевшая) - так говорят о коварной жене. Роли поменялись, и бывшая невестка превратилась в сварливую свекровь. Для сравнения в русском языке существует паремия: Брюзжит, как свекровь на невестку. Это доказывает, что в парах «свекровь - невестка» отрицательной коннотацией будет обладать лексема «свекровь», независимо от этнической принадлежности говорящего. Стереотипы выступают в роли основания оценки. С мачехой в любом языке, в том числе и аварском, ассоциируется представление о злобе, несправедливости, на основе чего развивается переносное значение «что-либо враждебное». При отборе гендерных пословиц и поговорок приходится сталкиваться с трудностями, когда непросто разграничить вышеназванные паремии от пословиц и поговорок о Родине, практической философии. С мачехой также часто сравнивают и чужие земли Жиндиргоракь - чохьолэбел, чиярракь - бесдалэбел (букв. «Своя земля - родная мать, чужая земля - мачеха»). Данную пословицу можно отнести и к группе пословиц о Родине.

В.Н. Телия отмечает, что оценка часто может меняться в зависимости от используемого контекста. Если говорящий - это честный, добрый человек любое его высказывание будет иметь положительную характеристику, в отличие от слов вредного, злого человека, которым сразу добавляется отрицательная оценка [7].

Оценочный статус паремиям в аварском языке придают категории «хорошо или плохо». С их помощью выражается оценка по поводу какой-либо ситуации, или поведения человека [8]. В пословицах, где отражаются брачные отношения, оценка варьируется от позитивной до негативной: Ч1ужуялда г1адин, рос льаларевила. «Никто не знает мужа так, как и жена». Ч1ужуквешил гьобол вохун унарев. «От того, у кого жена плохая, гости всегда уходят недовольные». Аварская жена - это, прежде всего хозяйка дома, хранительница семейного очага, гостеприимная. Поэтому вышеприведенная паремия имеет явно выраженную пейоративную оценку, что подчеркивает и определение «плохая». В аварском языке существует и вариативная паремия со схожим значением 41yжу квешасул мегеж хехго хъах1лъулеб. «У того, чья жена плохая, борода рано седеет».

С положительной стороны человека характеризуют такое качество, как ум. На примере паремий можно увидеть то, как относились горцы к людям образованным: ГІакъилав мискинчи къого бечедасдаса лъик1ав «Умный бедняк, лучше двадцати богачей», Г1акъиллъи бугелъуб, ярагъ х1ажалъулареб «Если есть ум, то оружие не понадобится». В этих пословицах оценочный компонент положительный, и хотя нет прямого указания на гендерную принадлежность субъекта, речь идет в первую очередь о мужчине. В аварском языке существуют паремии, характеризующие умственные способности человека, где гендерный фактор выражен явно: 41ужу г1акъилай яче: г1адалаб г1анк1уяль и1одораб хоно гьа- 
булареб. «Бери жену умную - глупая курица не несет умные яйца». Пример интересен еще и метафорическим переносом «Животное $\rightarrow$ Человек». Отрицательная оценка женского интеллекта отражена в паремии: Росасе инч10го, г1абдал лъаларей. «Дурочку не узнаешь, пока она не выйдет замуж». Метафорический перенос можно увидеть и в следующем примере: Ч1ужуялъе бокьани х1 амилги бихьинчи гьавулевила. «Если жена захочет, она из осла сделает мужчину». Здесь жена характеризуется положительно.

Немало в аварском языке паремий, построенных на противопоставлении таких качеств, как «храбрость трусость, нерешительность». В подобных паремиях часто упоминается слово «бах1арчи», например: Бах1 арчи цоц1ул хола, х1алихьат анц1ул холла «Храбрец умирает один раз, а подлец - десять», Бах1арчияс балъголъи хабалъе босулеб «Храбрец забирает правду с собой в могилу», Бах1 арчиясул ц1 ар кибего раг 1ула «Имя храбреца известно всем». Несмотря на то, что во всех приведенных примерах гендерная семантика выражена имплицитно, ясно, что речь идет о мужчине. Метафорический перенос можно обнаружить в пословице Лев и одряхлев, не станет лисой, олень и без зубов не осрамится. Трусость осуждалась, горцы с большим пренебрежением относились к трусливым людям, поэтому все паремии, где подчеркивается подобная черта характера, имеют отрицательную коннотацию. В этой связи интерес представляет следующая пословица: Пусть лучше мать умрет, чем родum mруса. В аварском языке существует паремия, где отмечается храбрость женщины и осуждается слабость мужчины: Ч1ужуяльул багьаяв гьеч1ев росги вук1уневила, анц1го росасул багьаяй ч1ужуги йик1унейила. «Бывают мужчины, которые не достойны жены, а бывают женщины, которые лучше десяти мужчин».

Аварцы с большим уважением относились к трудолюбивым людям, а лень, напротив, осуждалась, что нашло отражение и в паремиях. Х1алт1и катил г1адав, кванайх1амилг1адав «Работает как кот, а ест, как осел», Х1алт1изе кканихерав, хвезеккани бах1арав «Когда нужно работать, слишком стар, когда пора умирать - молод».
Гендерная семантика представлена в скрытом виде. Эксплицитно она прослеживается в другом выражении: ч1ужуяль рослъи гьабиги дурго г1айиб, васас эменлъи гьабиги-дурго г1айиб. «Сам виноват в том, что жена стала мужем, и если сын становится отцом, тоже сам виноват».

Много в аварском языке гендерных паремий, характеризующих болтливых людей. Принято считать, что данная черта свойственна в первую очередь женщинам: Росасул рек1ель бугеб жо ч1ужуяльул к1алдиб бук1унеб. «То, что у мужа на уме, бывает у жены на языке». Однако есть пословица, в которой отмечается различие между женой и разведенной женщиной: Росал ругез рокъоб бицунеб, къоролзабаз корохъ бичунеб. «Жены рассказывают обо всем дома, так же, как и разведенные в пекарне». Здесь жены характеризуются с положительной стороны.

У аварцев (как и у большинства народов) безнравственность была осуждаема. Мужчины и женщины с уважением относились к институту брака, моральным устоям, тем не менее, в языке существует ряд паремий, в которых попираются семейные ценности, причем как со стороны мужчины: Ч1ужуялъе зар кьолев, йокьулелъе рак1 кьолев. «Жене показывает кулак, а любовнице отдает свое сердце», так и со стороны женщины: Рос квешлъани, ч1ужуялъ чияхъ рокьи гьабула. «Если муж будет плохим, то жена найдет, кого любить». Обе паремии имеют явно выраженную отрицательную коннотацию.

Оценочность гендерных паремий аварского языка вопрос многоаспектный и недостаточно изученный. Оценка отражает способ отношения человека к миру. Большинство аварских пословиц и поговорок с гендерной семантикой имеют пейоративную окраску. Паремии с мелиоративной оценкой становятся нормой и не всегда фиксируются в языке. В ряде случаев коннотативное значение в пословицах выражается имплицитно. Нередко гендерные паремии образуются по метафорической модели: Животное $\rightarrow$ Человек. Гендерные паремии аварского языка национально-специфичны, что проявляется в определенном составе пословиц и поговорок для оценивания реалий окружающего мира.

\section{ЛИТЕРАТУРА}

1. Динь Вьет Кьюнг. Способы репрезентации оценки в языке // Филологические науки. Вопросы теории и практики. 2016. №2(56). 4.1. - С. 94 - 96.

2. Авар кицаби ва абиял. Аварские пословицы и поговорки /сост.Заирбек и Саид Алихановы. - М.: МИД, 2013. - 567 с.

3. Мудрые слова. Пословицы и поговорки народов Кавказа / сост. А.П. Куцко. - Нальчик: Эльбрус, 1979. - 73 с.

4. Магомедханов М.М. Очерки по фразеологии аварского языка. - Махачкала: Дагучпедгиз, 1972. - 160 с.

5. Восканян Г.Р. Жизнь паремиологических единиц в языке // Теоретические и прикладные аспекты исследования языков народов Северного Кавказа и других регионов мира. Симпозиум VIII.Ч.ІІ. Материалы IV Международного конгресса «Мир на Северном Кавказе через языки, образование, культуру». 21 - 24 сентября 2004. -Пятигорск, 2004. - С. $22-24$.

6. Апресян Ю.Д. Лексическая семантика (синонимические средства языка). 2-е изд., испр. и доп. - М.: Языки русской культуры, Издательская фирма «Восточная литература» РАН, 1995. - 470 c. 
7. Телия В.Н. Русская фразеология. Семантический, прагматический и лингвокультурологический аспекты. - М: Языки русской культуры, 1996. - 288 с.

8. Алиева Ш.З. Лексические и синтаксические особенности пословиц и поговорок аварского языка: автореф. дис. ... канд. филол. наук. - Махачкала, 2016. -22 c.

○ Алиева Самая Азеровна (samaya.alieva.00@mail.ru ), Гамзатова Сакинат Рустамовна (s_gamzatova@bk.ru).

Журнал «Современная наука: актуальные проблемы теории и практики»

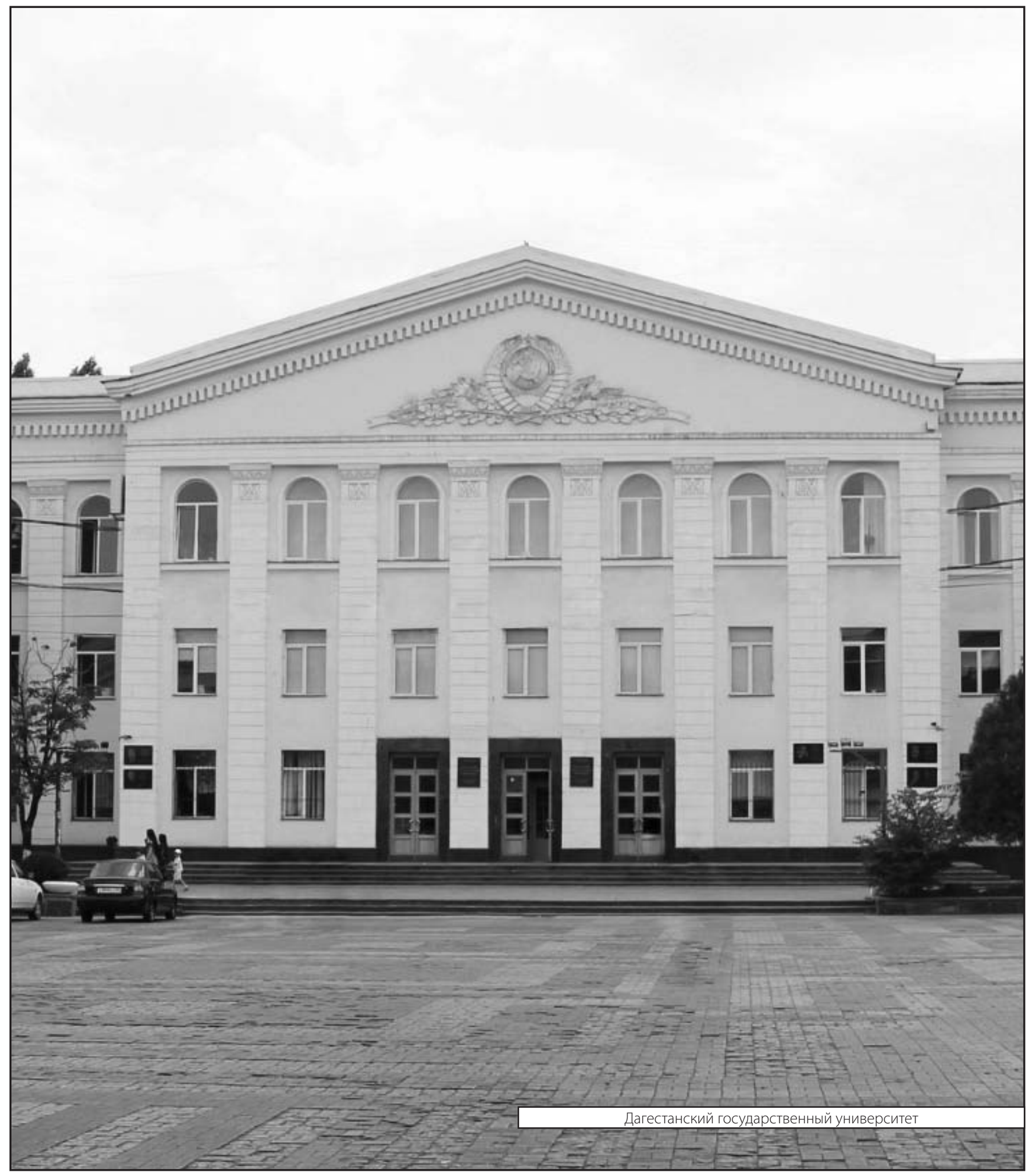

